\title{
Effect of Captopril on Blood Pressure and Renin-Angiotensin-Aldosterone System in Hypertensive Patients on Hemodialysis
}

\author{
Hiroshi Kaneda, Toyoaki Murata, Jun Matsumoto, \\ Takakichi Maeta, Kozo Shitomi and Takeshi Haruyama* \\ Clinic of Renal Disease, Iwaki-Kyoritsu General Hospital, \\ Iwaki 973 and *Clinic of Internal Medicine, Joban City \\ Hospital, Iwaki 972
}

\begin{abstract}
Kaneda, H., Murata, T., Matsumoto, J., Maeta, T., Shitomi, K. and Haruyama, T. Effect of Captopril on Blood Pressure and Renin-AngiotensinAldosterone System in Hypertensive Patients on Hemodialysis. Tohoku J. exp. Med., 1982, 137 (1), 21-31 — We have performed a long-term (6-16 months) administration of captopril in 6 hypertensive patients with renal failure undergoing hemodialysis. They were divided into two groups according to the basal renin levels (pretreatment plasma renin activity, PRA), that is, high PRA group (3 patients) and normal PRA group (3 patients). 1) In the high PRA group efficient reduction of blood pressure was obtained by small doses of captopril. In the normal PRA group, however, slight or no pressure reduction was observed. Appropriate initial dose was $10-15 \mathrm{mg} /$ day and maintenance one was $75 \mathrm{mg} /$ day in high PRA group. 2) Hemodialysis potentiated the hypotensive action of captopril in the high PRA group through massive removal of sodium and water. 3) In the normal PRA group PRA was regulated by serum sodium concentration and the plasma aldosterone concentration (PAC) was by serum potassium concentration, but in the high PRA group PRA and PAC were mainly regulated by captopril itself. 4) In one patient an adverse reaction consisting of strong bradycardia, dyspnea, chest pain and cold sweat was observed soon after the start of captopril medication. From these results, it was concluded that captopril was an excellent drug for the control of severe hypertension in dialysed patients having a high basal renin level. captopril; dialysis treatment; plasma renin activity
\end{abstract}

Captopril (SQ 14,225), a new orally active inhibitor of angiotensin I converting enzyme (kininase II, Erdös 1975), has recently been shown to be effective in the treatment of essential (Case et al. 1978; Gavras et al. 1978; Brunner et al. 1979; Johnston et al. 1979) as well as renal hypertension (Brunner et al. 1979; Kaneda et al. 1981). Captopril is also known to lower the severe hypertension (malignant hypertension, Abe et al. 1980) in dialysed patients.

Numerous studies have been made on the treatment of essential hypertension with captopril, but reports on dialysed patients are scarce in the literature (Brunner et al. 1979; Kaneda et al. 1981). In these situations, it is worthwhile to study the effectiveness of captopril in patients on hemodialysis, to determine the

Received for publication, January 9, 1981. 
proper initial and maintenance doses in these patients, and to examine the adverse reactions, if any.

We have had such. an experience in 6 severe hypertensive patients on hemodialysis. Three out of six patients had high plasma renin activity (pretreatment PRA), and responded excellently to the administration of captopril. On the contrary, the remaining three had normal basal PRA, and exhibited no excellent results on captopril. Subsequently, the factors influencing the effectiveness of captopril were analysed. The results will be reported below.

\section{Materials and Methods}

Six patients studied here were 5 males and one female. Their ages ranged from 24 to 63 with an average of 48, and their durations of dialysis ranged from 6 to 61 months, averaging 30. The periods of the treatment with captopril ranged from 6 to 16 months, the mean being 11. Their underlying diseases were essential hypertension (4 patients) and chronic glomerulonephritis (2 patients).

Six patients were divided into two groups according to the levels of basal plasma renin activity (PRA), that is, high PRA group (3 patients) and normal PRA group (3 patients). The clinical data of the two groups are listed in Table 1.

In all patients treated with captopril, PRA and PAC were measured once a week. Determination of PRA was done according to Abe et al. (1972, normal range; $5.0-30.0 \mathrm{ng} / \mathrm{ml}$ from April 1972 to May 1978 and 0.4-2.4 ng/ml from June 1978 to now). PAC was determined by the method of Ogihara et al. (1977, normal range; $10-100 \mathrm{pg} / \mathrm{ml}$ ).

All patients were treated by hemodialysis through arteriovenous fistula, two or three times per week, and were on a restricted sodium diet (approximately $100 \mathrm{mEq}$ or less per day). The concentration of dialysate was as follows: $\mathrm{Na}^{+}, 135-145 \mathrm{mEq} /$ liter, $\mathrm{Cl}^{-}, 103.0$ $\mathrm{mEq} /$ liter, $\mathrm{K}^{+}, 0-3.3 \mathrm{mEq} / \mathrm{liter}, \mathrm{Ca}^{++}, 3.5 \mathrm{mEq} / \mathrm{liter}, \mathrm{Mg}^{++}, 1.5 \mathrm{mg} / 100 \mathrm{ml}$, and acetate, 30-37 mEq/liter. Sodium, potassium, and acetate concentrations in dialysate were adjusted in each patient according to the state of electrolytes balance.

The dialysate supplying system was composed of a 50 liters tank and recirculation system, so that the fluid and electrolytes dialysed out of the body were easily calculated at the end of the dialysis. The removed substances were routinely analysed and recorded in each dialysis. Statistical analysis was carried out using Student $t$-test.

TABLE 1. The results of two groups divided according to the

\begin{tabular}{|c|c|c|c|c|c|c|c|}
\hline \multirow{3}{*}{ Case } & \multirow{3}{*}{$\begin{array}{l}\text { Age/ } \\
\text { Sex }\end{array}$} & \multirow{3}{*}{$\begin{array}{l}\text { Duration of } \\
\text { dialysis } \\
\text { (months) }\end{array}$} & \multirow{3}{*}{$\begin{array}{l}\text { Underlying } \\
\text { disease }\end{array}$} & \multirow{2}{*}{\multicolumn{2}{|c|}{$\begin{array}{c}\begin{array}{c}\text { Blood pressure } \\
(\mathrm{mmHg})\end{array} \\
\text { Captopril }\end{array}$}} & \multirow{2}{*}{\multicolumn{2}{|c|}{$\begin{array}{c}\text { PRA } \\
(\mathrm{ng} / \mathrm{ml}) \\
\text { Captopril }\end{array}$}} \\
\hline & & & & & & & \\
\hline & & & & Before & After & Before & After \\
\hline \multicolumn{8}{|c|}{ High PRA group } \\
\hline H.F. & $49 / \mathrm{M}$ & 61 & $\mathrm{EH}^{*}$ & $191 / 109$ & $166 / 101$ & 4.8 & 6.3 \\
\hline S.M. & $56 / \mathrm{M}$ & 6 & $\mathrm{EH}$ & $183 / 109$ & $154 / 90$ & 4.6 & 4.8 \\
\hline S.Y. & $31 / \mathbf{F}$ & 7 & $\mathrm{EH}$ & $201 / 130$ & $157 / 105$ & 5.0 & 6.3 \\
\hline \multicolumn{8}{|c|}{ Normal PRA group } \\
\hline K.K. & $63 / \mathrm{M}$ & 20 & $\mathrm{EH}$ & $172 / 100$ & $164 / 96$ & 2.0 & 2.1 \\
\hline S.O. & $62 / \mathrm{M}$ & 42 & $\mathrm{CN}+$ & $199 / 115$ & $190 / 111$ & 0.4 & 0.6 \\
\hline K.K. & $24 / \mathrm{M}$ & 41 & $\mathrm{CN}$ & $182 / 105$ & $169 / 98$ & 1.5 & 2.4 \\
\hline
\end{tabular}




\section{Results}

Case reports

A representative case of each group is described below.

Case 1 (high PRA group). A 49 years old male (Case H.F.) was found to have hypertension $(190-150 / 100-90 \mathrm{mmHg})$ in 1972. In July 1975, he visited a hospital to be diagnosed as severe hypertension with hypertensive nephropathy. In September 1975, he was admitted to our hospital complaining of strong emaciation (10 kg loss of body weight during the preceding 8 months), palpitation, severe headache, edema on legs, and advanced hypertension.

On his admission, severe hypertension $(234 / 140 \mathrm{mmHg}$ ), hyponatremia (134 $\mathrm{mEq} /$ liter), advanced retinal changes (KW-III), and deteriorated renal functions (BUN, $49 \mathrm{mg} / 100 \mathrm{ml}$; serum creatinine, $7.7 \mathrm{mg} / 100 \mathrm{ml}$; and $24 \mathrm{hr} \mathrm{Ccr}, 7.7 \mathrm{ml} / \mathrm{min}$ ) were noted. From these results, he was diagnosed as malignant hypertension and were treated with propranolol $(20 \mathrm{mg} /$ day) in September 1975 .

Plasma renin activity (PRA) measured on September 30, 1975 was markedly elevated $(65.0 \mathrm{ng} / \mathrm{ml})$. Propranolol was increased from $20 \mathrm{mg}$ to $60 \mathrm{mg} / \mathrm{day}$, and clonidine (0.45 mg/day), $\alpha$-methyl dopa (750 mg/day) and bethanidine (30 mg/day) were added. Despite these treatments, the hypertension did not improve, and BUN and creatinine were still elevating.

On November 16, 1975, hemodialysis, three times per week, was started for the treatment of severe hypertension and advanced azotemia. Antihypertensive drugs were administered intensively as follows: $\alpha$-methyl dopa $(1,500 \mathrm{mg} /$ day $)$, clonidine $(0.90 \mathrm{mg} /$ day $)$, bethanidine $(60 \mathrm{mg} /$ day $)$, nifedipine $(60 \mathrm{mg} /$ day $)$, and propranolol $(210 \mathrm{mg} /$ day). But the hypertension was not controlled at all.

On July 17, 1979, hypertension worsened $(226 / 135 \mathrm{mmHg})$ and orthopnea appeared, indicating emergence of congestive heart failure. On July 18, 1979, captopril (SQ 14,225) was administered with a dramatic effect (Fig. 1). Clinical course of the patient from July 18 to 23, 1979 was illustrated in Fig. 2.

\begin{tabular}{|c|c|c|c|c|c|}
\hline \multirow{2}{*}{\multicolumn{2}{|c|}{$\begin{array}{c}\text { PAC } \\
(\mathrm{pg} / \mathrm{ml}) \\
\text { Captopril }\end{array}$}} & \multicolumn{4}{|c|}{ Captopril } \\
\hline & & \multirow[t]{2}{*}{$\begin{array}{l}\text { Period } \\
\text { (months) }\end{array}$} & \multirow{2}{*}{$\begin{array}{c}\text { Initial dose } \\
\text { (mg/day) }\end{array}$} & \multirow{2}{*}{$\begin{array}{c}\text { Maintenance } \\
\text { dose } \\
\text { (mg/day) }\end{array}$} & \multirow[t]{2}{*}{ Side effects } \\
\hline Before & After & & & & \\
\hline 398 & 115 & 16 & 25 & 75 & $\begin{array}{l}\text { Bradycardia, dyspnea } \\
\text { cold sweat }\end{array}$ \\
\hline 345 & 64 & 6 & 20 & 75 & $(-)$ \\
\hline 580 & 88 & 7 & 10 & 75 & $(-)$ \\
\hline 50 & 42 & 15 & 25 & 225 & $(-)$ \\
\hline 80 & 39 & 16 & 25 & 300 & $(-)$ \\
\hline 220 & 144 & 6 & 15 & 150 & $(-)$ \\
\hline
\end{tabular}


H.F. 49 years, male

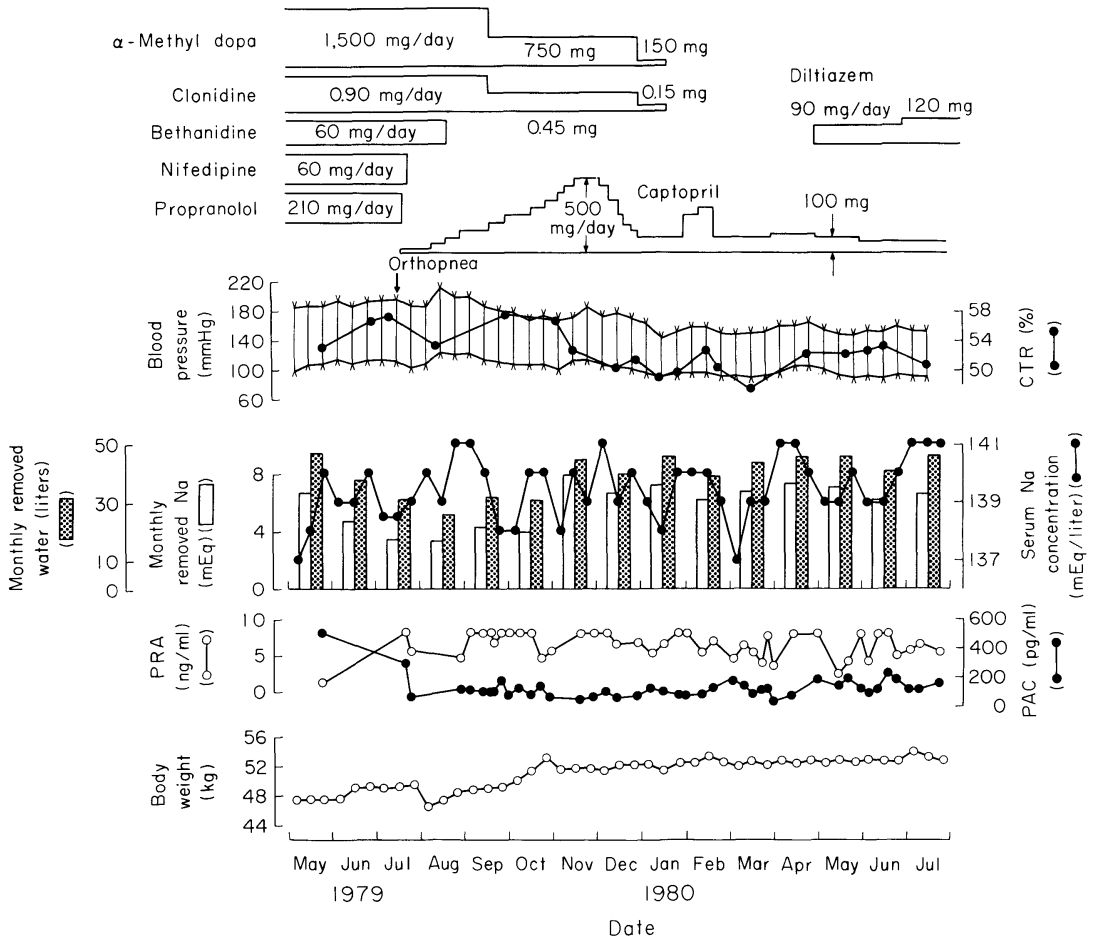

Fig. 1. The clinical course of a patient (Case H.F., 49 years old, male) having a high renin level.

\section{HF 49y, male}

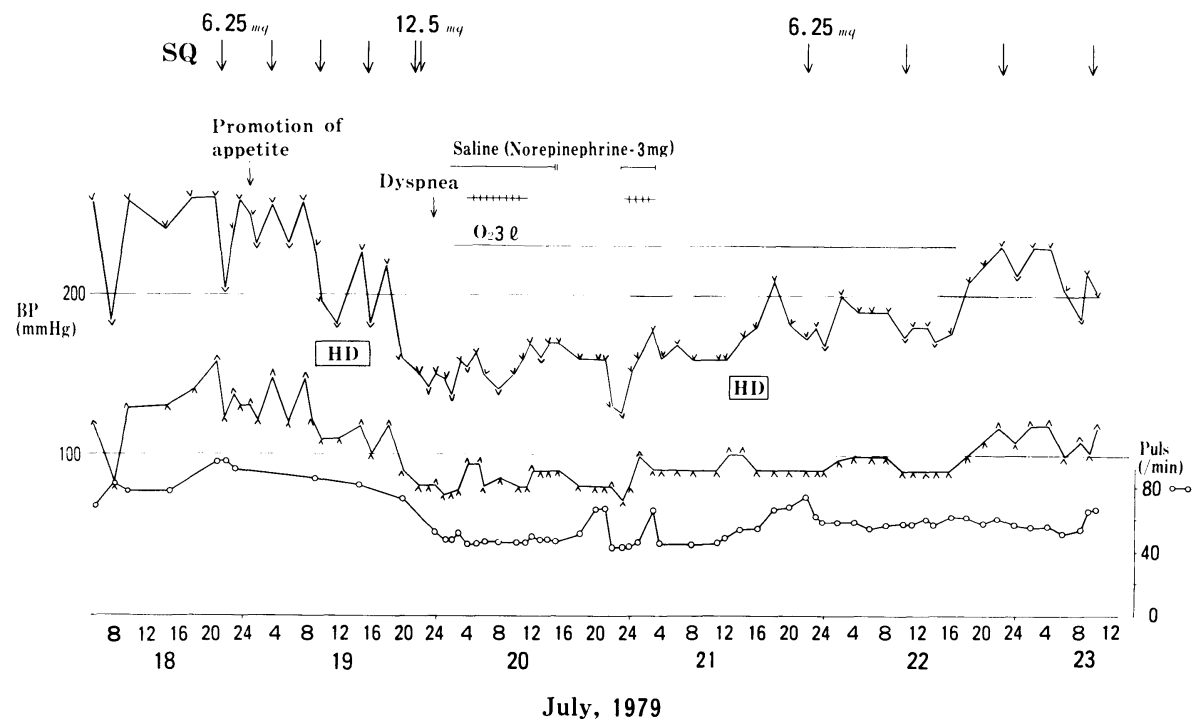

Fig. 2. The clinical course of the patient (Case H.F.) from July 18 to July 23, 1979. 
Initial dose of captopril was $25 \mathrm{mg} /$ day $(6.25 \mathrm{mg}$ every $6 \mathrm{hr}$ ).

Soon after the start of captopril administration, he felt well and his appetite improved which lasted thereafter.

On July 19, the dialysis was started as usual at 9:00 and ended at 16:00. On this day, his blood pressure and pulse rate were still descreasing, and at 20:00, $12.5 \mathrm{mg}$ of captopril was administered. Subsequently, his blood pressure and pulse rate were further decreased.

At 0:00 on 20th of July his blood pressure was $140 / 80 \mathrm{mmHg}$, pulse rate was $50 / \mathrm{min}$, and cold sweating, palpitation, and dyspnea were observed. It seemed likely that these symptoms might result from an acute reduction of blood pressure due to captopril. Three $\mathrm{mg}$ of norepinephrine dissolved in $500 \mathrm{ml}$ saline was immediately infused, and oxygen inhalation was performed. By these treatments, the patient's condition gradually improved but bradycardia remained unchanged for a while. Captopril was again medicated in a reduced dose of 6.25 mg at 20:00 on July 21st as shown in Fig. 2. Thereafter, such an acute reduction of blood pressure or bradycardia did not recur.

Propranolol and nifedipine were stopped in July 1979, and bethanidine was also discontinued in August 1979 (Fig. 1). Captopril was gradually increased up to $500 \mathrm{mg} /$ day in November 1979 .

From November 1979 to July 1980, the amounts of sodium and water removed monthly by the dialysis were $6,947 \mathrm{mEq}$ and 44 liters on an average, respectively. These values were distinctly larger than those in the initial stage of dialysis (from June to October $1979,4,028 \mathrm{mEq}$ and 21 liters). The differences were statistically significant (for sodium $p<0.005$, and for water $p<0.005$ ).

In accordance with these increased removal of sodium and water, blood pressure and cardio-thoracic ratio remained low in spite of the reduction of captopril and discontinuation of $\alpha$-methyl dopa and clonidine.

From June to October 1979, mean systolic blood pressure was $190 \mathrm{mmHg}$ and mean diastolic was $112 \mathrm{mmHg}$. From November 1979 to July 1980, the former was $159 \mathrm{mmHg}$ and the latter was $97 \mathrm{mmHg}$.

These results suggest that the massive removal of sodium and water by the dialysis strongly influenced the hypotensive action of captopril on blood pressure.

From May 1980, diltiazem (90-120 mg/day) was medicated in combination with captopril (75-100 mg/day), and then, further reduction of blood pressure was obtained.

In July 1980, mean systolic blood pressure was $150 \mathrm{mmHg}$ and mean diastolic was $90 \mathrm{mmHg}$. His general condition was greatly improved and he was discharged from the hospital to be treated as an out-patient.

As for the PRAs and PACs during the treatment of captopril, PRAs were constantly high, whereas PACs were greatly suppressed. 


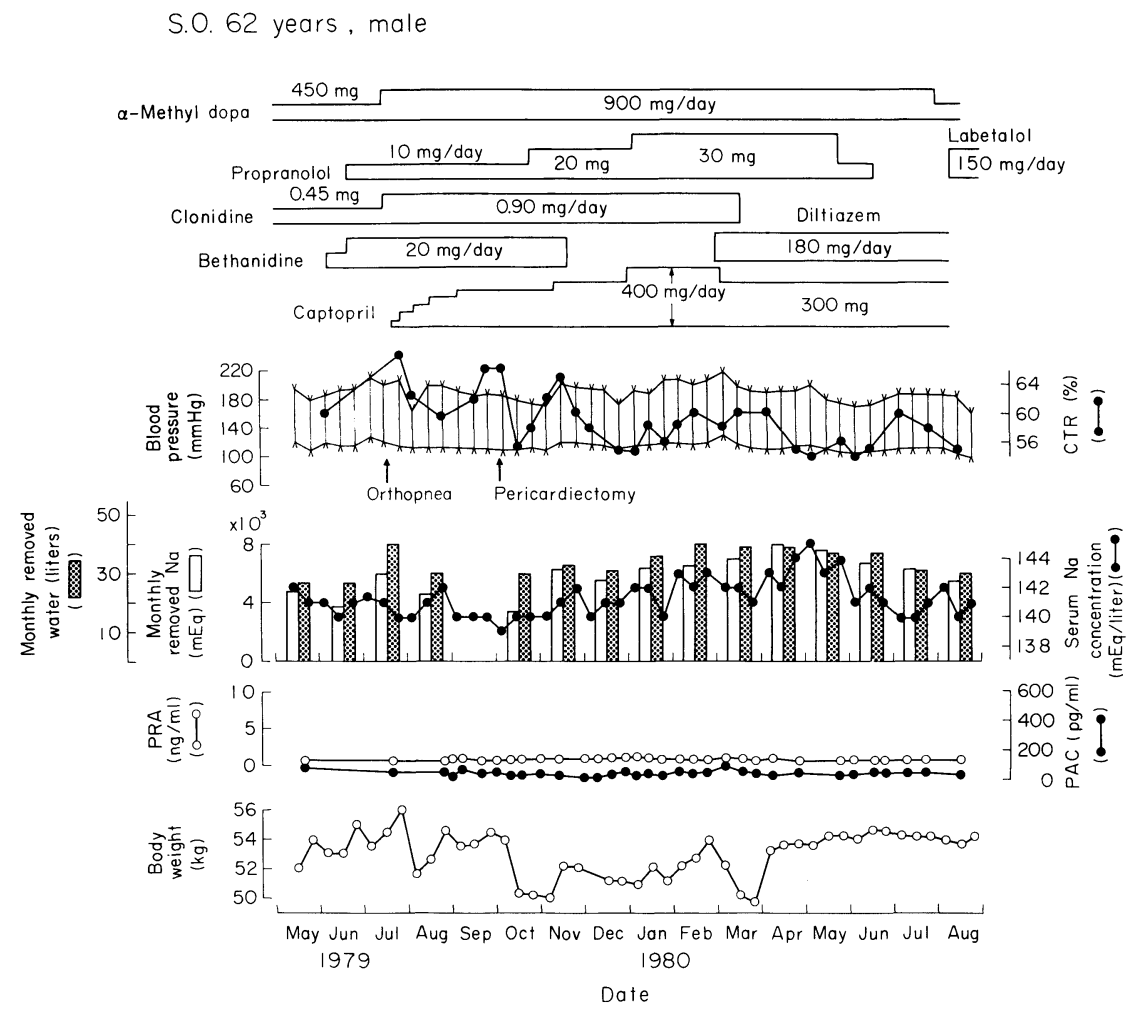

Fig. 3. The clinical course of a patient (Case S.O.) with a subnormal renin level.

1976, he complained of nausea and headache. On July 24, 1977 he was admitted to our hospital complaining of anorexia, nausea, and headache. On his admission, severe hypertension $(190 / 120 \mathrm{mmHg}$ ), advanced azotemia (BUN, $98 \mathrm{mg} / 100 \mathrm{ml}$; serum creatinine, $12.3 \mathrm{mg} / 100 \mathrm{ml})$, and anemia $(\mathrm{Hb}, 6.4 \mathrm{ng} / \mathrm{ml})$ were characteristic.

Hemodialysis was started on May 28, 1977 to treat the advanced azotemia and uremic symptoms. Intensive dialyses, three times per week, or massive hypotensive drugs ( $\alpha$-methyl dopa, $450-900 \mathrm{mg} /$ day; clonidine, $0.45-0.90 \mathrm{mg} /$ day; bethanidine, $10-20 \mathrm{mg} /$ day, and propranolol, $20 \mathrm{mg} /$ day) were not effective for the reduction of blood pressure.

On July 27, 1979, he complained of orthopnea indicating an emergence of hypertensive heart failure. For the amelioration of heart failure, captopril was administered on July 19, 1979 (Fig. 3). As shown in Fig. 3, his blood pressure was not changed, though antihypertensive drugs including captopril were increased or newly supplemented, and monthly removals of sodium and water were intensified.

From May to October 1979, mean monthly removal of sodium was $4,200 \mathrm{mEq}$ and mean monthly removal of water was 30 liters. From November 1979 to August 1980 , the former was $6,619 \mathrm{mEq}$ and the latter was 35 liters by means of 
lowering the sodium concentration of dialysate and increasing the ultrafiltrate. Both removed sodium $(p<0.005)$ and water $(p<0.005)$ in the latter period of time were significantly larger than those in the former period. In spite of these massive removals of sodium and water in the latter period of time, however, the blood pressure $(191 / 112 \mathrm{mmHg})$ was not improved as compared with the former period $(192 / 112 \mathrm{mmHg})$.

As for the PRAs and PACs, both showed subnormal levels before and after the treatment of captopril.

\section{Effects of captopril on blood pressure and renin-aldosterone levels}

Mean levels of serum sodium concentration, serum potassium concentration, PRA, and PAC during the treatment of captopril are listed in Table 2. Mean serum sodium concentration during the treatment of captopril was $139.9 \mathrm{mEq} /$ liter in the high PRA group and $140.0 \mathrm{mEq} /$ liter in the normal PRA group, showing no significant difference between the two groups. Mean serum potassium concentration was $5.1 \mathrm{mEq} /$ liter in the high PRA group and $4.7 \mathrm{mEq} /$ liter in the normal PRA group, showing significant difference $(p<0.005)$ between the two groups. Mean PRA during the treatment of captopril was $6.2 \mathrm{ng} / \mathrm{ml}$ in the high PRA group and $3.8 \mathrm{ng} /$ $\mathrm{ml}$ in the normal PRA group. Mean PAC during the treatment of captopril was $109.4 \mathrm{pg} / \mathrm{ml}$ in the former and $47.8 \mathrm{pg} / \mathrm{ml}$ in the latter. PACs between the two groups were statistically different $(p<0.005)$, but PRAs were not.

Effects of dialysis on the hypotensive action in the two groups are listed in Table 3. Blood pressures on the first post-dialysis day were $189.6 / 109.4 \mathrm{mmHg}$ in the high PRA group without captopril treatment, and $160.3 / 98.2 \mathrm{mmHg}$ with it; the difference was significant in both systolic $(p<0.005)$ and diastolic $(p<0.01)$.

TABLE 2. Serum sodium concentration, serum potassium concentration, PRA, and PAC during the treatment of captopril in two groups

\begin{tabular}{lcccccr}
\multicolumn{1}{c}{ Group } & $\begin{array}{c}\text { Number of } \\
\text { patients }\end{array}$ & $\begin{array}{c}\text { Number of } \\
\text { examinations }\end{array}$ & $\begin{array}{c}\text { Serum sodium } \\
\text { concentration } \\
(\mathrm{mEq} / \mathrm{liter})\end{array}$ & $\begin{array}{c}\text { Serum potassium } \\
\text { concentration } \\
(\mathrm{mEq} / \mathrm{liter})\end{array}$ & $\begin{array}{c}\mathrm{PRA} \\
(\mathrm{ng} / \mathrm{ml})\end{array}$ & $\begin{array}{c}\text { PAC } \\
(\mathrm{pg} / \mathrm{ml})\end{array}$ \\
\hline High PRA & 3 & 57 & $139.9 \pm 0.2$ & $5.1 \pm 0.1$ & $6.2 \pm 0.2$ & $109.4 \pm 6.2$ \\
Normal PRA & 3 & 87 & $140.0 \pm 0.2$ & $4.7 \pm 0.1$ & $3.8 \pm 2.3$ & $47.8 \pm 4.0$
\end{tabular}

Mean \pm s.D.

TABLE 3. Blood pressures on the first post-dialysis day and the second post-dialysis day in two groups with or without captopril treatment

Blood pressure $(\mathrm{mmHg})$

The 1st post-dialysis day The 2 nd post-dialysis day

High PRA group Captopril (-) Captopril $(+)$

Normal PRA group

Captopril (-)

Captopril $(+)$
189. $6 \pm 4.4 / 109.4 \pm 2.5$

160. $3 \pm 1.4 / 98.2 \pm 1.2$

183. $1 \pm 1.9 / 105.9 \pm 1.2$

$175.4 \pm 1.4 / 101.8 \pm 1.0$
194. $3 \pm 6.7 / 116.3 \pm 4.4$ 165. $3 \pm 2.3 / 100.3 \pm 1.5$

178. $0 \pm 2.8 / 102.2 \pm 1.8$ $179.8 \pm 1.7 / 104.4 \pm 1.0$ 
TABLE 4. Correlations between serum sodium concentration and PRA, between serum sodium concentration and $P A C$, between serum potassium concentration and $P A C$, and between $P R A$ and $P A C$

\begin{tabular}{|c|c|c|c|c|c|c|}
\hline & \multicolumn{3}{|c|}{ High PRA group } & \multicolumn{3}{|c|}{ Normal PRA Group } \\
\hline & $\begin{array}{c}\text { Number of } \\
\text { examina- } \\
\text { tions }\end{array}$ & $\begin{array}{c}\text { Correlation } \\
\text { coefficient } \\
(r)\end{array}$ & $\begin{array}{c}\text { Level of } \\
\text { significance } \\
(p)\end{array}$ & $\begin{array}{c}\text { Number of } \\
\text { examina- } \\
\text { tions }\end{array}$ & $\begin{array}{c}\text { Correlation } \\
\text { coefficient } \\
(r)\end{array}$ & $\begin{array}{c}\text { Level of } \\
\text { significance } \\
(p)\end{array}$ \\
\hline \multicolumn{7}{|l|}{ PRA vs. } \\
\hline $\begin{array}{l}\text { Serum sodium } \\
\text { concentration }\end{array}$ & 57 & -0.07 & n.s. & 87 & -0.29 & 0.05 \\
\hline PAC & 57 & -0.10 & n.s. & 87 & 0.03 & n.s. \\
\hline \multicolumn{7}{|l|}{ PAC vs. } \\
\hline $\begin{array}{l}\text { Serum potassium } \\
\text { concentration }\end{array}$ & 57 & 0.07 & n.s. & 87 & 0.34 & 0.01 \\
\hline $\begin{array}{l}\text { Serum sodium } \\
\text { concentration }\end{array}$ & 57 & -0.19 & n.s. & 87 & 0.12 & n.s. \\
\hline
\end{tabular}

Blood pressures on the first post-dialysis day were $183.1 / 105.9 \mathrm{mmHg}$ in the normal PRA group without captopril treatment, and $175.4 / 101.8 \mathrm{mmHg}$ with captopril; also the difference was significant in both systolic $(p<0.005)$ and diastolic $(p<$ $0.025)$.

Blood pressures on the second post-dialysis day were $194.3 / 116.3 \mathrm{mmHg}$ in the high PRA group without captopril treatment, and $165.3 / 100.3 \mathrm{mmHg}$ with it; the difference was significant in both systolic $(p<0.025)$ and diastolic $(p<0.05)$. Blood pressures on the second post-dialysis day were $178.0 / 102.2 \mathrm{mmHg}$ in the normal PRA group without captopril treatment, and $179.8 / 104.4 \mathrm{mmHg}$ with it; the difference was not significant in either systolic or diastolic.

As for the blood pressures under captopril treatment in the two groups, there was no statistically significant difference in either systolic or diastolic between the first and second post-dialysis days.

Correlations among serum sodium concentration, serum potassium concentration, PRA, and PAC during the treatment of captopril are shown in Table 4. Between serum sodium concentration and PRA, significant correlation was found only in the normal PRA group $(r=-0.29, p<0.05)$. Between serum sodium concentration and PAC, no significant correlation was found in either group. Between serum potassium concentration and PAC, significant correlation was found in the normal PRA group $(r=0.34, p<0.01)$, but not in the high PRA group. Between PRA and PAC, no correlation was recognized in either group.

\section{Discussion}

Introduction of captopril (SQ 14,225, D-2-methyl-mercaptopropanoyl-Lproline) into the clinical trials was an epoch-making event in the treatment of hypertension. Specific inhibition of angiotensin-converting enzyme (Ferguson et al. 1977; Ondetti et al. 1977) and feasibility of oral administration are two 
major characteristics of this drug. Many studies related to captopril have proved that this drug is effective for essential hypertension as well as for renal hypertension, and it is more effective for high renin type hypertension (Case et al. 1978; Brunner et al. 1979) than for normal or low renin type in which it shows slight hypotensive action owing to bradykinin potentiation (Ondetti et al. 1977; McCaa et al. 1978; Brunner et al. 1979) or unknown mechanism. Most studies on captopril had been done in essential hypertension, but in patients with renal failure and hypertension, the effect of captopril had been studied in few institutions (Brunner et al. 1979; Kaneda et al. 1981).

We performed a long-term treatment of 6 hypertensive patients on hemodialysis with captopril, and the following results were obtained.

1) Hypotensive action and basal renin levels.

Patients having high basal renin activity in the plasma (mean value of PRA, $4.8 \mathrm{ng} / \mathrm{ml}$ ) responded with excellent reduction of blood pressure compared to the normal renin group (mean value of PRA, $1.3 \mathrm{ng} / \mathrm{ml}$ ). Case et al. (1978) and Brunner et al. (1979) reported similar results. It was, however, an interesting fact that patients with normal PRA also showed slight hypotensive response to the administration of captopril. It was not certain whether this hypotensive effect of captopril in the normal PRA group resulted from potentiation of bradykinin (Ondetti et al. 1977; McCaa et al. 1978; Brunner et al. 1979) or other unknown mechanisms.

2) Appropriate initial and maintenance doses of captopril in hypertensive patients under hemodialysis.

Case H.F., one day after the dialysis, received $25 \mathrm{mg} /$ day of captopril as an initial dose and presented severe hypotension, bradycardia, and dyspnea. He did not show such symptoms thereafter, though much larger doses of captopril were administered and intensive dialysis treatment was carried out. To avoid this excessive hypotension, the initial dose of captopril in dialysed patients should be limited to small doses (10-15 mg/day).

On the other hand, the maintenance dose in the high PRA group was $75 \mathrm{mg} /$ day as a mean, but in the normal PRA group it was $225 \mathrm{mg} /$ day. Blood pressures were efficiently controlled in the former by small doses of the drug, but not excellently regulated in the latter by massive doses of the drug.

From these results, it was concluded that the optimal maintenance doses of captopril in patients sensitive to the drug (high PRA group) might be relatively small and comparable to those in essential hypertension.

3) Relationship between the hypotensive action of captopril and the dialysis treatment.

The high PRA group responded to captopril with significant blood pressure reduction on both the first and second days after the dialysis, whereas the normal PRA group responded only on the first day after the dialysis. From these results, it was obvious that hypotensive action of captopril was strengthened by the dialysis treatment. 
Removal of sodium and water from the body, enhancing the renin-angiotensin system, is likely to intensify the hypotensive action of captopril. Similar observation has been made in patients with essential hypertension treated with diuretics (Case et al. 1978; Brunner et al. 1979; Johnston et al. 1979).

4) Regulation of PRA and PAC in patients treated with captopril.

PRA was correlated negatively with serum sodium concentration in the normal PRA group, but not in the high PRA group. On the contrary, PAC was significantly correlated with serum potassium concentration in the normal PRA group, but not in the high PRA group. From these results, PRA and PAC may be regulated by captopril itself, independently of electrolytes balance, in the high PRA group, but not in the normal PRA group, in which they were dependent on electrolytes balance.

\section{Acknowledgment}

We gratefully acknowledge Professor Kaoru Yoshinaga and Dr. Keishi Abe, the Second Department of Internal Medicine, Tohoku University School of Medicine, Sendai, for their advice in preparing this manuscript. Our thanks are also due to Dr. Yasuo Hatakeyama, Director of Iwaki-Kyoritsu General Hospital, Iwaki and Dr. Nobuhide Mimura, Director of the Department of Nephrology, Toranomon General Hospital, Kanagawa.

\section{References}

1) Abe, I., Kawasaki, T., Ueno, M., Kawano, Y., Uezono, K., Ogata, M., Kawazoe, N. \& Omae, T. (1980) Usefulness of orally active angiotensin I converting enzyme inhibitor (SQ 14225) in the treatment of malignant hypertension. Fukuoka Acta med., 71, $157-166$.

2) Abe, K., Otsuka, Y., Saito, T., Chin, B.S., Aoyagi, J., Miyazaki, S., Irokawa, N., Seino, M., Miura, Y., Ono, I., Minai, K., Kobayashi, K., Sato, T. \& Yoshinaga, K. (1972) Measurement of plasma renin activity by angiotensin I radioimmunoassay: a modification of Haber's method. Jap. Circulat. J., 36, 741-749.

3) Brunner, H.R., Gavras, H., Waeber, B., Kershaw, G.R., Vukovich, R.A., McKinstry, D.N. \& Gavras, I. (1979) Oral angiotensin-converting enzyme inhibitor in long-term treatment of hypertensive patients. Ann. intern. Med., 90, 19-23.

4) Case, D.B., Atlas, S.A., Laragh, J.H., Sealey, J.E., Sullivan, P.A. \& McKinstry, D.N. (1978) Clinical experience with blockade of renin-angiotensin-aldosterone system by an oral converting-enzyme inhibitor (SQ 14,225, Captopril) in hypertensive patients. Progr. cardiovasc. Dis., XXI, 195-206.

5) Erdös, E.G. (1975) Angiotensin I converting enzyme. Circulat. Res., 36, 247-255.

6) Ferguson, R.K., Turini, G.A., Brunner, H.R. \& Gavras, H. (1977) A specific orally active inhibitor of angiotensin-converting enzyme in man. Lancet, 1, 775-778.

7) Gavras, H., Brunner, H.R., Turini, G.A., Kershaw, G.R., Tifft, C.P., Cuttelod, S., Gavras, I., Vukovich, R.A. \& McKinstry, D.N. (1978) Antihypertensive effect of the oral angiotensin converting-enzyme inhibitor SQ 14225 in man. New Engl. J. Med., 298, 991-995.

8) Johnston, C.I., Millar, J.A., McGrath, B.P. \& Matthews, P.G. (1979) Long-term effects of captopril (SQ 14225) on blood pressure and hormone levels in essential hypertension. Lancet, 2, 493-496.

9) Kaneda, H., Murata, T., Matsumoto, J., Maeta, T. \& Shitomi, K. (1981) Treatment of hypertension in patients with dialysis. Kidney and Dialysis, 10, 161-175. (Japanese)

10) McCaa, R.E., Hall, J.E. \& McCaa, C.S. (1978) The effects of angiotensin-I-converting enzyme inhibitors on arterial blood pressure and urinary sodium excretion. Role of 
the renal renin-angiotensin and kallikrein-kinin system. Circulat. Res. (Suppl. I), 43, 32-39.

11) Ogihara, T., Iinuma, K., Nishi, K., Arakawa, Y., Takagi, A., Kurata, K., Miyai, K. \& Kumahara, Y. (1977) A non-chromatographic non-extraction radioimmunoassay for serum aldosterone. J. clin. Endocr., 45, 726-731.

12) Ondetti, M.A., Rubin, B. \& Cushman, D.M. (1977) Design of specific inhibitor of angiotensin converting enzyme: new class of orally active antihypertensive agents. Science, 19, 441-444. 